\title{
Outside of the Self: Subjectivity, the Allure of Transcendence, and Jazz Historiography
}

\section{Ryan Sawyer McCormack}

The point at issue [in Human, All Too Human] was the value of the non-egotistical Instincts, the instincts of compassion, self-denial, and self-sacrifice, which Schopenhauer above all others had consistently guilded, glorified, "transcendentalized" until he came to see them as absolute values allowing him to deny life and even himself. Yet it was these very same instincts which aroused my suspicion, and that suspicion deepened as time went on. It was here, precisely, that I sensed the greatest danger for humanity, its sublimest delusion and temptation-leading it to whither? Into nothingness?

-- Friedrich Nietzsche, The Genealogy of Morals

Vasil Parmakov, one of the great jazz pianists, authors, and humorists in post-communist Bulgaria makes the following statement in a short essay about jazz posted on his Facebook page in the spring of 2011:

When a Bulgarian jazz musician gets into the company of foreigners, they usually ask him whether he is playing Bulgarian jazz. The guy tries to explain that (you see) he is Bulgarian. Making music. Therefore-it is music made by a Bulgarian. There is nothing else to be. It's simple logic.

I find what this statement says about the conceptualization of self to be both humorous and illuminating. One of Parmakov's primary aims was to downplay the "gaze" of the foreign tourist toward the Balkan object, a part of the relationship between Bulgaria and Western Europe since the nineteenth century. ${ }^{1}$ At the same time, though, I see his critique as a subtle yet poignant statement on the uses of "jazz" as a platform for subject construction. He sees no need for the Bulgarian musician to be constructed from the outside by the tourists' imaginations and desires. The observers' attempts to facilitate a "transcendence" from their idea of Bulgaria seems misplaced and unwarranted to the pianist's mind.

This essay is an attempt to rethink the role of transcendence in the politics and poetics of jazz historiography, in consideration of the growing body of scholarship on jazz practice outside of the United States. More specifically, I explore the allure of constructing "transcendence" in jazz discourse at the level of subjectivity, leading to the creation of the "transcendental improvising subject." The relationship between "transcendence" and subjectivity has a long history in Western philosophy, dating back to Descartes' position of the thinking subject as the center of metaphysics. In much of jazz historiography, "transcendence" has been adopted as a central subject position through which the individual musician utilizes musical expression to move into a higher state of being. The link to transcendence in jazz stems from a complex amalgamation of elements from Western philosophy, Christian spirituality, and the suffering of African Americans under slavery, Jim Crow, and white supremacy. Constructing the subject utilizing transcendence is therefore reflective of a politics of African American identity not easily applicable outside the United States.

My critique of transcendence's allure draws on post-Kantian European writings about transcendental subjectivity and modernity, where notions of a cohesive "transcendence" away from embodied aspects of the self is deemed both dangerous and magical. Unlike the intellectual tradition of American pragmatism from which much of the "transcendental improvising subject" is based, this post-Kantian tradition more stringently undermines the immutable construction of such a subject position in a way that much jazz historiography does not. I ultimately argue that the "transcendental improvising subject" is both an object of affection and an object of identity politics. It is constructed by the polyphony of discourses and fetishizes (intentionally or unintentionally) the irreducible American-ness of "free individuals beyond time [. . .] reified as a first principle from which both musicians and theorists find their ultimate social meaning" (Gebhardt 134). To underscore both the "dangerous" and "magical" aspects of the transcendental improvising subject, I close this article with some brief examples from jazz performance outside the United States, where I will show how the construction of such a homogeneous subjectivity can obscure localized projections of (and anxieties toward) performing subjectivities. 


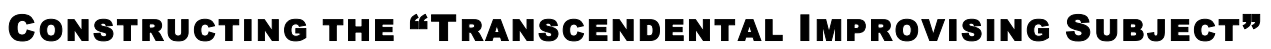

Understanding the allure of transcendence in jazz historiography first requires an understanding of how transcendence has been actualized in subject construction by jazz musicians, listeners, critics, and scholars. George Lipsitz writes the most poetic articulation of transcendence's role in this process in his introduction to the essay collection Uptown Conversation: The New Jazz Studies. Here, he formulates a pointed critique of Ken Burns' controversial 2001 documentary Jazz, a project that valorized the "genius" jazz musician transcending the travails of American modernity, one of the narrative backbones of the jazz canon. ${ }^{2}$ To undermine Burns' evangelical romanticism of the jazz musician, Lipsitz utilizes the trope of "Darby Hicks," a fictional musician that bandstand veterans of Harlan Leonard's Territory Jazz Band would use in their interactions with younger musicians. The Hicks trope, Lipsitz argues, served as both a disciplinary mechanism amongst the band's members and an ideal type against which musicians judged their craft—no matter how much one practiced or performed, "Darby Hicks" would always be a better player. He was part urban legend, part Weberian ideal, and part spiritual embodiment of the potential in every young musician to achieve greatness in the face of social, cultural, and economic barriers.

Lipsitz argues that Ken Burns' documentary has "more than a little of Darby Hicks in it" (10), referring to the construction of a narrative that privileges particular modes of time, space, and being that separate "jazz" as a unique and homogeneous form of cultural expression. Specifically, Lipsitz is critical of the attempt by Burns and his colleagues to "compress the infinitely diverse and plural practices that make up the world of jazz into one timemodernity, one place-'America,' and one subjectivity — the heroic artist who turns adversity and alienation into aesthetic triumph" (10). Lipsitz readily admits that this strategy to celebrate the place of the African American artist in the modern urban milieu is commendable and part of an intellectual tradition perpetuated through the works of African American literary and musical critcism. ${ }^{3}$ At the same time, he argues that this mechanism also obscures broader social formations, practices, and community building that facilitated the construction of such a romantic narrative.

"Darby Hicks"- what I call the "transcendental improvising subject"-is in many ways an articulation of, to borrow from Mikhail Bakhtin, the "polyvocality" of perspectives and desires that construct the jazz musician as simultaneously subject and object. This polyvocality includes the musicians themselves, critics, scholars, fans, record producers, and anyone else whose imaginations were complicit in casting musicians as homogeneous objects of desire. The term also encompasses the social and historical forces that cast jazz as a syncretism of modernity, urbanness, blackness, and American exceptionalism. This heroic narrative of the improvising subject transcends body, space, and desire to actualize a deeper need to transcend the social and cultural limitations of twentieth century America. Thus the contemporary romanticism of Burns, Marsalis, and others dallies with the metaphysics of transcendence through ideas of a "jazz community" in the United States and the travails and politics of musicmaking. ${ }^{4}$

The conflation of polyvocality with transcendence in jazz scholarship and criticism is outlined nicely by David Ake in a chapter about the posthumous construction of John Coltrane from his recent book Jazz Matters. He argues that the possibility of multiple subjectivities is manifest through musical performance interpreted and mapped by the listener, subjectivities that he labels as being, becoming, and transcendental. These subjectivities are "personas" through which listeners hear and imagine "who Coltrane was as a person and what his performances mean" (17). While being and becoming are modes of self through which subjectivity maintains a temporal engagement in the present, transcendental captures the sense of the "musical persona's 'ego' giv[ing] way to a larger totality [. . .] when a musician blends in with fellow players such that one no longer perceives individual voices but rather a densely concentrated mass of sound" (31).

Ake's articulation of a transcendental subject constructed through engagement with a "larger totality" pinpoints how transcendence emphasizes within jazz discourse a socially poignant dislocation from the violence and stress of the everyday. Ceding the rationality of one's ego to the pens of writers and the ears of listeners translates a musician's subjectivity into, borrowing from Deleuze, a rhizomatic assemblage that reaches beyond the body itself, a process reminiscent of Sartre's notion that the appearance of the Other to the self is that of a "transcendence-transcended" (315). "Darby Hicks" therefore becomes not only an ideal to codify musicians' desires through self-discipline, but also a promise of escape into the phantasmagoria of mythology, discourse, and memory.

This construction of transcendence as a mechanism that disembodies the subject into a totality of cultural aesthetic has deep roots in the philosophical influences on the African American intellectual and literary community after WWII. Walton Muyumba, for example, argues that African American writers like Ralph Ellison, James Baldwin, and Amiri Baraka, active during the height of bebop's influence, wrote in the vein of an American pragmatism originating with Ralph Waldo Emerson and adopted in the philosophical positions of W.E.B DuBois and Alain Locke at the turn of the twentieth century. Emerson was a champion of the inherent "American-ness" of the American thinker, and Ellison and Baldwin rearranged this concept through their interpretation of the blues as a literary aesthetic. Utilizing the blues in 
this way was a mechanism by which the contentious and fractured identity of the black artist could be codified. "With concern to identity," Muyumba writes that the "blues idiom expression accentuates our tragicomic desires for connection to both our essential selves and our need for ethnocentric unity. We understand, however, that we will find an essential or absolute self because our identities are complex, elusive, jagged, multiple, and fragmented" (16).

I read Muyumba's position on Emersonian pragmatism as in part a warning against casting the subject positions perpetuated by Ellison and Baraka through the Eurocentric lens of a neo-Kantian transcendental idealism. Although I agree to some extent with Ingrid Monson's warning against "the equation of the disempowered [. . .] with the transcendental subject that is the object of Western philosophy's antihumanist critique" (Saying Something 213), I argue that this equation stems in part from the very pragmatic positions perpetuated in the Black intellectual community by musicians, critics, and listeners. In the "modern" jazz musician these intellectuals found an ideal candidate to actualize the desire to create a socially and aesthetically modern, immutable Black subject equal to (or even surpassing) its White counterpart. Monson herself alludes to such a point in her later work:

To become one's own theorist—to have one's concept that in turn leads to the expression of one's own voice-was among the highest aesthetic ideals of the [jazz] art form. To become an improviser at this high level was to become aesthetically self-determining in a world in which other forms of self-determination or agency were more easily frustrated. This was an existential rather than a social self-determination, in other words. (Freedom Sounds 286)

Transcendence, as a mechanism of self-determination, frames these "highest aesthetic ideals" as an escape from the travails that Black artists faced. Simultaneously, it reinforces the context-specific importance of such subject construction, where one's experiences of those travails are a key ingredient for transcendence to be reached. George Lewis' work on the history of the AACM in Chicago is influential in showing the ways this collective strove to foster individual musical and aesthetic ambitions through mutual economic and spiritual support. Consider one of the primary lessons Muhal Richard Abrams taught in his composition classes at the collective during the 1960s: "We're listening to stuff that's around us, and then we can transcend [emphasis mine]. We're not captive to the usage of things around us, the empirical part" (qtd. in Lewis 177). Abrams is vague in this case on the specific usage of "transcend", but the allegory that he presents is clear. In transcending basic compositional technique, the self also transcends environment and the sum of experience.

The examples presented from the work of Muyumba, Monson, and Lewis suggest that,the intuiting of subject positions within jazz performance has been inexorably intertwined with the historical relationship between power and racism in America. Musicians adopting, even embracing, the meme of transcendence in the ways Monson and Abrams describe is perhaps unsurprising given the host of postcolonial literature dedicated to the adoption of language and the rhetoric of Western philosophy in the service of subaltern motives. Henry Louis Gates Jr. and Emmanuel Chukwudi Eze highlight the dismissal by many Enlightenment philosophers, including Kant and Hegel, of the possibility of a modern, thinking "African" subject. Paul Gilroy alludes to a similar phenomenon by highlighting the "strategic universalism" of Black discourses as a way to transcend the dehumanization of racism in everyday life. The deconstruction of racialized discourses within the language of Western thought became an even more powerful force during the Civil Rights era, when the postwar generation of African American philosophers and aestheticians continued the process of building a Black modernity that had evolved from the ideals of the Harlem Renaissance. With regard to music, this process culminated in Baraka's works on black aesthetics: Blues People (1963) and Black Music (1967). Here, he acerbically argues that the power of the white-driven culture industry in America has deterred the development through blues and bebop of an aestheticized Black subjectivity by co-optation of forms such as rock 'n roll-a process he famously dubs "The Great Music Robbery" (Black Music 328).

Within such an environment, recourse to transcendence as a mechanism of self-preservation within the co-optation of cultural forms seems almost inevitable. Ralph Ellison's work, in particular, places a great deal of emphasis on the aesthetics that manifest the transcendent as a means of "reducing the chaos of living to form" (Porter 15); but Ellison (and James Baldwin and Edward Poole to some extent) grounds his conceptualization of transcendence in what Krin Gabbard calls a "quasi-religious moment" (335). Gabbard uses this term as a means to show how African American intellectuals often broke down articulations of spiritual transcendence along racial lines during the 1960s. Most notably, he draws on Baraka's dichotomous descriptions of Louis Armstrong and Bix Beiderbecke from Blues People: while the black Armstrong was considered to be "an honored priest of his culture," the white Beiderbecke was "an instinctive intellectual" pushing consciously and subconsciously against the social and cultural norms of white Midwestern bourgeois life (Baraka 154, qtd. in Gabbard 335).

The potential allure of transcendence for writers, fans, and musicians-Ake's extra-ego totality-becomes very clear in light of the desires of the African American intellectual community in the 1950s and 1960s. The allure of 
(re)claiming a subject position that, to Baraka and others, had been co-opted over and over again by White America became an integral part of the valorization of bebop and hard bop by a younger generation of musicians during the 1980s. More importantly, intellectual engagement with transcendence by Baldwin, Baraka, and others powerfully influenced how improvisation, subjectivity, and jazz historiography was subsequently discursively constructed by scholars, leading to the development of a number of "subjective recovery" projects of pre-WWII American artists who didn't have the benefit of Baraka, Baldwin, Whitney Balliett, Nat Hentoff, or others to cast their modernity as transparent for a wider audience. A notable example of an artist whose "subjectivity" has received this treatment is Duke Ellington, who has been constructed though his own words and those of interlocutors as one of the first modern Black cosmopolitans in the history of American jazz. ${ }^{5}$ A host of others receiving similar treatment in recent books include Lester Young and a number of WWI-era Creole professional musicians in New Orleans. ${ }^{6}$

As Lipsitz's critique surrounding "Darby Hicks" and the preceding argument may suggest, Burns' romantic narrative cannot even begin to encompass all the culturally and temporally specific constructions of jazz and its practitioners, or the "transcendental improvising subject" that his narrative perpetuates. My critique of this narrative specifically reflects on the allure that transcendence holds as a technology of subjective recovery and coherence, precisely what led Walter Benjamin to famously refer to transcendence as a "most fearful drug [. . .] which we take in solitude" (qtd. in Palladino 220). If this is the case, what value is there in exposing the problematic aspects of transcendence for jazz historiography as its mode and scope of inquiry expands beyond the United States?

The biggest problem that I see with the "transcendental improvising subject," as it is constructed through "Darby Hicks" and the legacy of Emersonian pragmatism, is the assumption that the motion of transcendence is solely one of upward mobility - away from the self. In fixing it as a route away from the confines and tribulations of self, transcendence takes on political and ethical dimensions regarding the African American experience of modernity: valorizing transcendence in this way thrusts various forms of immanent, embodied, or contextual critique on subjectivity in jazz to the periphery (even those as apropos and engaging as Lipsitz's). I propose another way to approach transcendence, one that lays bare the problematic construction and subjective damage of the "transcendental improvising subject" within its own philosophical and historical roots. By highlighting a particular postKantian critique of transcendental subjectivity in Western Europe from around 1850, I hope to create new possibilities for interpreting transcendence as something that encompasses the self and grounds transcendental experiences within the body, rather than without. This critique offers a different take on European writings about jazz from the first half of the twentieth-century (like those of French critic Hugues Panassié) that have been roundly criticized for their racialization of the Black body. ${ }^{7}$ While certainly suspect in their claims about the function and forms of those bodies, these works also expose the internal fallacies of transcendence in ways that more widely accepted writings about jazz have found difficult to articulate.

\section{The “Transcendental Subject" and Embodiment}

The mid-nineteenth century European turn toward a transcendence located within the subject itself begins with the writings of Søren Kierkegaard. ${ }^{8}$ In his 1849 work The Sickness unto Death (Sygdommen til Døden), Kierkegaard argues that the "double movement of the self" in the act of subject recognizing the Other as such means that the recognition of such transcendence requires yet another form of transcendence. This new form involves reinscribing the self in what Aren Grøn calls a "seek[ing . . .] beyond themselves in the sense that they want to be more than human, or to be more human than others" (25). Whether or not this kind of transcendence inevitably leads to "idolization or self-deification," as Kierkegaard states, is up for debate. For Kierkegaard, the "double movement" that outlines the transcendent recognition of subjectivity only occurs when the self recognizes itself as just as human as the Other: "a master who is a self directly before his slaves is no self" (79).

Kierkegaard's relocation of transcendence in, rather than away from, the subject draws upon the legacy of various critiques of the transcendent "I" that date back further than the philosophical canon generally attributes, to the lateeighteenth and early-nineteenth centuries. ${ }^{9}$ More importantly, though, Kierkegaard (perhaps unintentionally) extends this inquiry via German Idealism to the possibility that transcendence can be directly related to biological processes. If the true nature of transcendence is in recognizing oneself as more rather than less human, then the immanent self becomes a possible site of transcendence.

Kierkegaard was obviously not considering jazz or its politics of transcendence when writing Sygdommen til Døden; nevertheless, his profound recognition of the self, and thus the body, as a possible site for a transcendental subjectivity produces a compelling way to assess the impact of "jazz" on debates about the nature and possibility of a transcendental subject in Europe after the First World War. As the European powers became more and more embroiled in the politics of Africa during the late-nineteenth century, the social realities of such policies became more explicit through the philosophical construction of a self vetted through the colonial imagination. The "double 
movement of the self" that introduced the body as a transcendental frame melded with European notions of an "African" aesthetics of the body to create an avenue of critique that borrowed from discourses on colonial race theory. A similar process had already begun to occur in the United States, where Ronald Radano shows that the "prediscursive, 'spiritual' resonance" of African American music was melded with alarm at the prospect of African American's "hot rhythm" entering the social and economic spaces of white society (460-61). The adoption of blackface minstrelsy, ragtime, and (later) early jazz into the culture industry of capitalism provided an avenue through which theorists such as Adorno, Horkheimer, and Benjamin could press Kierkegaard's critique of an immutable transcendence even further-into the realms of popular culture, mass media, and the crisis of art in the age of mechanical reproduction.

The widespread popularity of African American art forms, coupled with their dissemination through recording and radio, coincided with a deep questioning of the ontological status of art as immutably beautiful. Issues of the "transcendental subject" questioned since the mid-nineteenth century were pulled into this debate as well, often framed as the dissolution of the subject within the mechanizing processes of modernity. Sigfried Kracauer, for example, used "jazz" in his 1925 essay "Travel and Dance" to emphasize the disintegration of the transcendental subject via modernity's co-optation of time and space, as well as to highlight the acts required by subjects to orient their frames of knowledge within that modern world. Jazz, in his mind, thrust the subject into a one-dimensional existence empty of meaning, what he called a "tempo that is concerned with nothing but itself" (qtd. in Burt 82). Such an existence perpetuated the subjugation of the individual into a "henchman of technological excesses" where subjects "do not become masters of the machine, but instead become machine-like" (qtd. in Burt 70).

For Kracauer, the possibility of transcending the self within the machinations of modern life is a trap, with "jazz" the alluring feature that lures the subject inside modernity's temporal and spatial rhythms. Read in light of Kierkegaard's writings on transcendental subjectivity, however, a different meaning emerges that is far less dystopic. Kracauer's warning against becoming "machine-like" can also refer to the impossibility of transcending the self through the aesthetics and technologies of modernity. The troubling part is the way that "jazz" is utilized as a means to convince the self that such transcendence is not only possible, but desirable. Lacking Kierkegaard's necessary "double movement" and intimacy with the humanity of the Other, transcendental subjectivity becomes nothing more than an empty spectacle, Kracauer's "one-dimensional existence" empty of meaning (82).

This alternative politics of transcendence via Kierkegaard, where utilizing aesthetic expression as a means to transfer the self is foreclosed due to the nature of transcendence itself, reaches its pinnacle in the writings of Theodor Adorno, although the critique lies within the polyvocality of critical discourse from various scholars and aestheticians that both includes and subsumes Adorno. Indeed, Adorno's ideas about jazz ironically suffer from the same kinds of political manipulations as the "transcendental improvising subject": this polyvocality that reshapes Adorno articulates better than anything the problems of a universalized subject position based within the ontology of transcendence. Almost poetically, Adorno's ideas critique transcendence by transcending Adorno himself.

Adorno argues that instead of liberating subjectivity through aesthetic engagement, the Culture Industry stifles the subject by opening a pathway to the basest of libidinal desire through the simulacra of "authentic" Black cultural forms. Some have argued that Adorno's limited knowledge of jazz falsely fueled his vitriol, though others assert that he was far more educated about jazz than most criticism of his work suggests. ${ }^{10}$ Whatever Adorno's perceived faults, his writings on jazz represent a remarkable perspective on the subject's relationship to power and the Cultural Industry. James J. Winchester effectively summarizes this take on subjectivity by stating that, for Adorno, "no artistic production is purely subjective [. . . ] that which the subject expresses is [ . .] both personal and a product of the subject's social world" (115).

Adorno's turn here to the socially placed subject is a direct critique of the perceived solipsism and free expression inherent in the Enlightenment conceptualization of individuality. In his mind, jazz improvisation was particularly liable to the perversions of such "pseudo-individualism" because of its complicity in the reification of image and sound under capitalism. The potential for resistance against jazz's disease of pseudo-individualism lay, somewhat ironically, in the mimetic potentials inherent in the act of improvisation itself. Adornian mimesis, as Amresh Sinha suggests, "is not about replicating the content [of the object]; rather it is a form of expression" in which expression itself is the only residual of the artistic act (1). This expression, as Michael Taussig reminds us, thus takes the form of a sensuous materiality with the object, one in which the subjective autonomy of the artist is undetachable from art's aura. With improvisation, the visceral physicality of playing—of David Sudnow's "articulational reach" or Vijay lyer's embodied improvisation-provides a mimetic counter-narrative that undermines the disembodying ideal of the transcendent. While I grant that Adorno likely didn't have the phenomenology of craft in mind when emphasizing the role of mimesis in the rehabilitation of improvisation, he was most certainly aware of the potential for mimesis to place improvisation within the purview of the embodied transcendent. 
At the same time, Adorno saw no recourse to the ideology of collectivization and, like his contemporary Louis Althusser, was distrustful of the totalizing aspects of such ideology. Instead, Adorno worked this problem through the lens of the negative dialectic, settling on a space of negation that he terms the "oppositional group." Peters states that by "thinking [of] improvisation in terms of oppositional groups [Adorno] is able to suggest a mode of aesthetic expression that avoids the triviality of the subjective [. . .] while, at the same time, dialectically dynamizing objectivity by making its expressive potency dependent not on the intrinsic qualities of form but on the mimetic acts of artists" (85).

Peters essentially argues that the link between negation and mimesis was, for Adorno, a way to sidestep the problem of pseudo-individualism's false consciousness regarding subjective expression. Ceding the subject's will to the totality of transcendence is, however, equally problematic, making the socially placed subject the only viable option for Adorno-something of an interstitial compromise. This subjectivity rides the line between the embodiment of the visceral act and the disembodiment of the historian's pen, existing only in the making of art, dissolving into nothingness once it is objectified and moved into a mode where it represents something other than itself.

Adorno's writings address several memes that bring us back to Kierkegaard's original formulations of subjectivity. The utilization of the mimetic faculty of art and of the "oppositional group" based in the negative dialectic recalls Kierkegaard's essential role of the Other in understanding transcendence. More importantly, these writings identify aesthetic expression as the site in which possibilities cast upon transcendence are actualized within the realms of immanence and embodiment, a possibility that Kierkegaard never really considered. The foreclosure of the possibility of a disembodied, upward transcendence through the aesthetic act leaves the "transcendental improvising subject" as little more than an alluring conflation of desire, the "real" site of personal transcendence having nothing to do with transcendence at all.

Thus, conceptualizing transcendence as movement through the body and the self, as opposed to movement away from the self, can arguably undermine the universal potential at the heart of the wholly "American" pragmatism of Emerson, Ellison, and jazz historiography. In order to contextualize this claim, it is necessary to more tangibly explore the impact on jazz produced outside the United States of jazz historiography's politics of transcendence. One of the notable consequences of creating the "transcendental improvising subject" has been the historical marginalization of jazz performance from outside the United States. This marginality has been expressed most cogently in the "unoriginality" or "inauthenticity" of performance stemming from outside the experience of American modernity, a common critique of jazz practiced outside of the borders of the United States. The allure of living up to the "originality" or "authenticity" promised by the "transcendental improvising subject" is, I argue, the site through which the ethical authority of transcendence in jazz can finally be critiqued and collapsed.

\section{The Decay of the “Transcendental Improvising Subject”}

Historian George McKay, for example, gives a tangible example of such a sense of marginality with regard to the spread of jazz in Europe, and more specifically Great Britain, during the early twentieth century. He argues that perceptions of "unoriginality" tied to early imitations by British jazz musicians stemmed from two facets. The first was white Britons lionizing jazz as historical music of Black suffering, which "could itself have been part of its romance, a reductive strategy effectively confirming the social hierarchy and Black cultural practitioners' allotted place in it" (24). Such a position, McKay points out, drew suspicion from prominent Black musicians like Charles Mingus and Archie Shepp that jazz had become "part of the aggrandizing narrative of America the cultural hegemony, not even comfortably celebrated as recognition of a unique [African-American] contribution to world culture" (22). The second was the idea that jazz was experienced as "lingua Americana" via its primary dissemination as an instrumental form, making the music "not so much untranslatable as unnecessary to translate" from its American context (25).

A central facet of McKay's argument is that the tacit acceptance and complicity amongst Britons themselves in constructing a homogeneous subject position for the quintessential jazz musician had a profound effect on the attitudes toward jazz in Great Britain. A similar phenomenon occurred in France during the 1920s and 1930s. Jeffrey Jackson writes that the clamoring amongst the French public for "authentic" Black American performers was so intense that "jazz" performed by Frenchmen was deemed to be inferior in quality (26). This fetish of "otherness" in all its forms opened the door for the likes of Django Reinhardt and other "Gypsy jazz" musicians who built sizable intranational and international reputations through not being perceived as "white."11

The very embedded social nature of marginality in each of these examples, even when sharing a direct link via ideas of Americanness, speaks to the inherent problem in constructing a homogeneous subject position that encompasses place, space, identity, and subjectivity under one rubric. Adding to McKay's and Johnson's takes on Great Britain and 
France respectively are studies of Asian-American musicians relating their struggles for integration and independence to avant-garde African American musicians playing during the Civil Rights era and of South African musicians drawing upon intimate transatlantic connections to African American musicians present and past. ${ }^{12}$ Even with the acknowledgement by these and other scholars that a homogeneous, transcendent subjectivity is problematic in application, the extension of subjective recovery toward jazz musicians outside of the United States has intensified since the early-2000s, in conjunction with works by Ake, Nesbitt, and Porter that are centered in the United States. Though the place and time have changed, the story ostensibly sounds familiar-the improvising musician mediates the world away through performance, trumping everyday hardships and social barriers.

Paul Austerlitz's Jazz Consciousness is an excellent book that still utilizes the "transcendental improvising subject" in many of the ways that I outline above: Austerlitz draws upon different tenets of philosophical humanism in order to coherently link the author's experiences with African American, Dominican, and Finnish traditions into a single experiential frame of mind. He posits a reinterpretation of W.E.B. Dubois's "double consciousness" as a concept beyond its dialectical origins, one that encompasses both the lived realities of African Americans in the US and the performance of their music and culture across the world. At the crux of his argument is the idea that "musical consciousness" has a unique power to "unite things that are separated in nonmusical reality" (xiii). This consciousness manifests in the "jazz community" as a utopian space that cuts through racial, ethnic, gender, and class lines. Jazz becomes, he argues, a music through which individuals come together and share part of the "creative tension resulting from African Americans' equivocal position both within and without Western modernity" (xvi). In other words, Austerlitz argues that all human beings can relate through their own experiences to some piece of African American suffering, and that jazz can be a prime platform for playing out these "social ruptures" during performance.

While Austerlitz's position on a utopian space based on "creative tension" is not without merit, I argue that it falls into precisely the trap of transcendence-as-liberating-movement that Kierkegaard and others have warned about. Michael Titlestad gives one of the most poignant examples of how subjective recovery within a transcendental totality becomes both obscuring and traumatic when dealing with musicians outside of the United States. Utilizing what he calls "transmigrated nomenclature," Titlestad highlights a localized phenomenon in which South African jazz musicians and audiences "name" local musicians after iconic African American jazz musicians as a sign of legitimization and authenticity. Through the example of alto saxophonist Kippie Moeketsi, known popularly as the South African "Charlie Parker," Titlestad argues that these adopted identities give a sense of belonging and connection that transcends the empirical realities of life in apartheid South Africa. While the phenomenon itself is a fascinating example of the historical imaginations that Black South Africans had for African Americans going back the late nineteenth century, I would argue that it shows how pervasive, abstracting, and alluring the notion of a transcendental Black subject in jazz performance can be. Becoming-Charlie Parker is a privileged aesthetic space that taps into subjective desires to defer everyday suffering through multifaceted identities. Most importantly, Titlestad acknowledges the role listeners and writers can play in making subjects, in this case in imbuing a kind of immortality that belies a musician's material existence. Moeketsi lives in death beyond his own liminal means, embedded totally within the transcendent desires of his imaginers.

This imagining also becomes the point of subjective disruption in which notions of transcendence cease to be libratory for the subject in question and instead become an iron cage of identity. Transcendence, ironically, is no longer simply Benjamin's "fearful drug" for the subject itself, but a potent cocktail for the entire apparatus of Ake's "larger totality" of the imagination. What begins as an entree into an embodied timelessness becomes a disembodied fantasy that traumatizes the subject at the very moment when its redemption should be most secure. Titlestad captures very clearly in a summation of his short piece on Moeketsi's career the downside of constructing a vision of (an)other's subjectivity though discourse and imagination:

Improvisation, whether musical or ontological, both reflects and places the individual on trial. To exalt identity-in-process single-mindedly is to underrate the dangers that inhere in fluid and liminal subject positions. [. . .] We need, then, to dwell on the rupture-the space between the names-that potentially dislocates the human subject with the effect that he is neither here nor there. Moeketsi's greatest achievement, reaching across that space both musically and ontologically, also relates directly to his disorder and eventual silence. (163)

Within the point of "rupture" in the "space between the names" lies a space of self that the "transcendental improvising subject" is powerless to articulate. There are countless other examples of this from outside the spatial and temporal boundaries of the US: the Bulgarian pianist whose self-conscious anecdote about the "Bulgarian" jazz musician opens this essay, or loannis Tsioulakis, whose study of Athenian jazz musicians highlights a "frustrated cosmopolitanism" wherein they play jazz to escape the tedium of their professional careers. More tragically, there 
were young Japanese musicians who picked up heroin in the early-1950s in an attempt to occupy Charlie Parker's body, with predictably disastrous results (Atkins 203-4). Casting "Darby Hicks" as the ideal for musicians promises the veneer of liberation through transcendence of self, but also becomes a form of subjective violence, masking identities within the cloak of musical idols. And, as we have seen repeatedly, even the idols themselves are not safe.

\section{Notes}

${ }^{1}$ As a former territory of the Ottoman Empire from 1453 to 1878 , Bulgaria has long stood at the crossroads between Europe and Asia. As such, the complicated relationship between Bulgarians-as-Europeans and Bulgarians-as-Other has been a focal point for issues of identity in the region since the late nineteenth century. Maria Todorova's Imagining The Balkans stands as the most detailed and relevant expression to date of this complex of EuroOrientalism. For a more specific account of the European imagination of the Balkans as Other during the $19^{\text {th }}$ century, see Hammond. In addition, the writings of Bulgarian lawyer/adventurer Aleko Konstantinov (1863-1897) provide some of the most cognizant (and humorous) explorations of the Bulgarian proclivity to imagine themselves as part of the Western European social and cultural milieu. His famed novel Bai Ganyo and his travelogue To Chicago and Back have both been translated into English. For analyses of the social implications of Konstantinov's writing, see Daskalov and Neuburger.

2 The ten-episode, nineteen-hour PBS series' narrative was constructed with the purpose of, as Burns himself put it, "convinc[ing] someone in Dubuque [lowa] that jazz is the Rosetta Stone of American culture" (qtd. in Blumenthal 38). Burns' greatest coup during the production was securing trumpeter/composer/bandleader Wynton Marsalis as a technical advisor. Marsalis, the director of the Lincoln Center Jazz Orchestra in New York and recipient of the Pulitzer Prize for Music Composition for his epic jazz operetta Blood on the Fields, was at the time America's most publicly visible jazz musician and outspoken champion of the music's preservation. He was also, to his detractors, a staunch neoclassicist whose dismissal of post-1960s jazz drew ire from critics, journalists, and musicians alike.

${ }^{3}$ Baraka's (Leroi Jones) Blues People, Murray's Stompin' the Blues, and Baker's Modernism and the Harlem Renaissance were all critical works in the Civil Rights and post-Civil Rights construction of African American modernity in the United States.

${ }^{4}$ Lipsitz, for example, uses the career of Horace Tapscott and his deep reverence for the African American sacred tradition in his “Darby Hicks" article. Other notable examples include Ronald Radano's take on multiinstrumentalist/composer/philosopher Anthony Braxton and Nicole Rustin and Sherrie Tucker's essay collection on women in jazz.

${ }^{5}$ See Collier and Hasse.

${ }^{6}$ On Lester Young, see Lewis Porter's biography, and for the Creole musicians, see Ake's chapter in Jazz Cultures: "Blue Horizon: Creole Culture and Early New Orleans Jazz" (10-41).

${ }^{7}$ See Jordan (102-84) for an excellent analysis of the articulations and politicizations of blackness in Panassie's jazz writings, as well as an contextual grounding for the French ethnographic scholarship of the 1930s that served as the basis for much of Panassie's own thought. See also Grandt (129) for a brief mention of Leonard Feather's critique through his blindfold listening tests of the valorization of blackness by European critics.

${ }^{8}$ The complex relationship between "transcendence" and subjectivity has seen many incarnations through both Kant and others within the German Idealist tradition and beyond. The historical dichotomy between the transcendent and the immanent as cast by Kantian idealism and later the American transcendentalists is not nearly as rigid as often perceived, particularly with regard to the construction of the subject. The philosophical differences between what are broadly termed Emerson's "transcendentalism" and Kant's "transcendental idealism" require far more explication than this article has room to address. For a detailed analysis of transcendental idealism and its relationship to realism and deduction, see Allison. For history on the theory and practice of American transcendentalism through the work of Emerson, Thoreau, and Fuller, see Gura. For an explication on Kant's writing on the relationship between transcendental and empirical subjectivity, and the relationship of these subject positions to objective knowledge, see Caygill (240-43). 
${ }^{9}$ As Andrew Bowie has convincingly argued, the subversion and critique of the Kantian metaphysics most fervently attributed to the work of Foucault, Derrida, and others was prefigured by writings on aesthetics by contemporaries of Kant, and even by Kant himself (2). For example, Bowie shows that Jürgen Habermas's famous claim that postmetaphysical thinking would involve a "transfer[ence] from transcendental subjectivity to grammatical structures" was prefigured by F.D.E Schleiermacher's notion that language and grammatical structures were historically contingent, without an ahistorical relationship between language and being (185).

${ }^{10}$ See Lewandowski and Buhler.

${ }^{11}$ See Benjamin Given's essay on Reinhardt.

${ }^{12}$ On Asian American musicians, see Deborah Wong; on South African musicians, see Coplan, Erlmann, and Ballantine.

\section{Works Cited}

Ake, David. Jazz Cultures. Berkeley: U of California P, 2002. Print.

---. Jazz Matters: Sound, Place, and Time Since Bebop. Berkeley: U of California P, 2010. Print.

Allison, Henry. Kant's Transcendental Idealism: An Interpretation and Defense. Rev. Ed. New Haven: Yale UP, 2004. Print.

Atkins, E. Taylor. Blue Nippon: Authenticating Jazz in Japan. Durham, NC: Duke UP, 2001. Print.

Austerlitz, Paul. Jazz Consciousness: Music, Race, and Humanity. Middletown, CT: Wesleyan UP, 2005. Print.

Ballantine, Christopher. "Music and Emancipation: The Social Role of Black Jazz and Vaudeville in South Africa Between the 1920s and the Early 1940s." Jazz Planet. Ed. E. Taylor Atkins. Jackson, MS: U of Mississippi P, 2003. 169-90. Print.

Baraka, Amiri. Black Music. New York: W. Morrow, 1967. Print.

Blumenthal, Bob. “Ken Burns' Jazz.” JazzTimes Dec. 2000: 34-42. Print.

Bowie, Andrew. Aesthetics and Subjectivity: From Kant to Nietzsche. $2^{\text {nd }}$ Ed. Manchester: Manchester UP, 2003. Print.

Buhler, James. "Frankfurt School Blues: Rethinking Adorno's Critique of Jazz." Apparitions: New Perspectives on Adorno and Twentieth Century Music. Ed. Berthold Hoeckner. New York: Routledge, 2006. 103-30. Print.

Burt, Ramsay. Alien Bodies: Representations of Modernity, "Race," and Nation in Early Modern Dance. New York: Routledge, 1998. Print.

Caygill, Howard. A Kant Dictionary. Malden, MA: Blackwell, 1995. Print.

Collier, James Lincoln. Duke Ellington. New York: Oxford UP, 1987. Print.

Coplan, David. In Township Tonight! South Africa's Black City Music and Theater. New York: Longman, 1985. Print.

Daskalov, Roumen. "Modern Bulgarian Society and Culture through the Mirror of Bai Ganio." Slavic Review 60 (2001): 530-49. Print.

Erlmann, Veit. African Stars: Studies in Black South African Performance. Chicago: U of Chicago P, 1991. Print. 
Eze, Emmanuel Chukwudi, ed. Race and the Enlightenment: A Reader. Malden, MA: Blackwell, 1997. Print.

Gebhardt, Nicholas. Going for Jazz: Musical Practices and American Ideology. Chicago: U of Chicago P, 2001. Print.

Gates, Henry Louis. “Race,” Writing, and Difference. Chicago: U of Chicago P, 1986. Print.

---. The Signifying Monkey: A Theory of African-American Literary Criticism. New York: Oxford UP, 1989. Print.

Gilroy, Paul. Against Race: Imagining Political Culture Beyond the Color Line. Cambridge, MA: Belknap of Harvard UP, 2000. Print.

Givan, Benjamin. “Django Reinhardt's Left Hand.” Jazz Planet. Ed. E. Taylor Atkins. Jackson, MS: U of Mississippi P, 2003. 19-40. Print.

Grandt, Jürgen. Kinds of Blue: The Jazz Aesthetic in African American Narrative. Columbus, OH: Ohio State UP, 2004. Print.

Grøn, Arne. "Subjectivity and Transcendence: Problems and Perspectives." Subjectivity and Transcendence. Ed. Arne Grøn, Iben Damgaard, and Søren Overgaard. Tübingen, Germany: Mohr Siebeck, 2007. 9-36. Print.

Gura, Philip. American Transcendentalism: A History. New York: Hill and Wang, 2007. Print.

Hammond, Andrew. "The Uses of Balkanism: Representation and Power in British Travel Writing, 1850-1914." The Slavonic and East European Review 82 (2004): 601-24. Print.

Hasse, John Edward. Beyond Category: The Life and Genius of Duke Ellington. Cambridge, MA: Da Capo, 1995. Print.

lyer, Vijay. "Improvisation, Temporality, and Embodied Experience." Journal of Consciousness Studies 11 (2004): 159-73. Print.

Jackson, Jeffery. Making Jazz French: Music and Modern Life in Interwar Paris. Durham, NC: Duke UP, 2003. Print.

Jones, LeRoi. Blues People: Negro Music in White America. New York: Morrow Quill, 1963. Print.

Jordan, Matthew F. Le Jazz: Jazz and French Cultural Identity. Urbana-Champaign: U of Illinois P, 2010. Print.

Kierkegaard, Søren. The Sickness Unto Death. Trans. Walter Lowrie. Princeton: Princeton UP, 1941. Print.

Konstantinov, Aleko. To Chicago and Back. Trans. Robert Sturm. Sofia: Bulgarian Bestseller, 2005. Print.

---. Bai Ganyo: Incredible Tales of a Modern Bulgarian. Trans. Victoria A. Freidman et al. Madison: U of Wisconsin P, 2010. Print.

Lewandowski, Joseph. "Adorno on Jazz and Society." Philosophy and Social Criticism 22.5 (1996): 103-21. Print.

Lewis, George. A Power Stronger Than Itself: The AACM and American Experimental Music. Chicago: U of Chicago $P, 2008$. Print.

Lipsitz, George. "Songs of the Unsung: The Darby Hicks History of Jazz." Uptown Conversation: The New Jazz Studies. Ed. Robert G. O’Meally, Brent Hayes Edwards, and Farah Jasmine Griffin. New York: Columbia UP, 2004. 9-26. Print.

McKay, George. Circular Breathing: The Cultural Politics of Jazz in Britain. Durham, NC: Duke UP, 2005. Print. 
Monson, Ingrid. Saying Something: Jazz Improvisation and Interaction. Chicago: U of Chicago P, 1996. Print.

---. Freedom Sounds: Civil Rights Call Out to Jazz and Africa. Oxford: Oxford UP, 2007. Print.

Muyumba, Walton. The Shadow of the Act: Black Intellectual Practice, Jazz Improvisation, and Philosophical Pragmatism. Chicago: U of Chicago P, 2009. Print.

Neuburger, Mary. "To Chicago and Back: Aleko Konstantinov, Rose Oil, and the Smell of Modernity." Slavic Review 65 (2006): 427-45. Print.

Palladino, Paolo. Plants, Patients, and the Historian: (Re)membering in the Age of Genetic Engineering. Oxford: Manchester UP, 2002. Print.

Peters, Gary. The Philosophy of Improvisation. Chicago: U of Chicago P, 2009. Print.

Porter, Lewis. Lester Young. Ann Arbor, MI: U of Michigan P, 2005. Print.

Radano, Ronald. New Musical Figurations: Anthony Braxton's Cultural Critique. Chicago: U of Chicago P, 1993. Print.

---. "Hot Fantasies: American Modernism and the Idea of Black Rhythm." Music and the Racial Imagination. Ed. Ronald Radano and Philip V. Bohlman. Chicago: U of Chicago P, 2000. 459-80. Print.

Rustin, Nicole T. and Sherrie Tucker, eds. Big Ears: Listening for Gender in Jazz Studies. Durham, NC: Duke UP, 2008. Print.

Sartre, Jean Paul. Being and Nothingness: An Essay in Phenomenological Ontology. Trans. Hazel E. Barnes. New York: Citadel, 2001. Print.

Sinha, Amresh. "Adorno on Mimesis in Aesthetic Theory." In Practice: Adorno, Critical Theory and Cultural Studies. Ed. Holger Mathias Briel and Andreas Kramer. Bern, Switz.: Lang, 2000. 145-59. The Walter Benjamin Research Syndicate. Web. 25 April 2012.

Sudnow, David. Ways of the Hand: The Organization of Improvised Conduct. Cambridge, MA: MIT UP, 1993. Print.

Taussig, Michael. Mimesis and Alterity: A Particular History of the Senses. New York: Routledge, 1993. Print.

Titlestad, Michael. Making the Changes: Jazz in South African Literature and Reportage. Boston: Brill, 2004. Print.

Todorova, Maria. Imagining the Balkans. New York: Oxford UP, 1997. Print.

Tsioulakis, loannis. "Jazz in Athens: Frustrated Cosmopolitians in a Music Subculture." Ethnomusicology Forum 28 (2011): 175-99. Print.

Wong, Deborah. Speak It Louder: Asian Americans Making Music. New York: Routledge, 2004. Print. 